\title{
A Lesson Learn from Empowerment Program of Integrated Cassava-Tapioca Agroindustry Actors in Pati District, Indonesia
}

\author{
Eva Banowati \\ Department of Geography, Faculty of Social Science, Universitas Negeri Semarang
}

Received: 2019-11-23

Accepted: 2020-07-27

Keywords:

empowering program; integrated agroindustry;

lesson learn;

social-science.

Correspondent email: evabanowatigeo-

grafi@mail.unnes.ac.id

\begin{abstract}
Frequently, empowering models for cassava farmers is programmed by government, but unsuitable to socio-geographic conditions, such as in Pati District. This study was aimed to depict social knowledge and lesson learn of cassava-tapioca agroindustry actors, and to understand the farmers' acceptance, before and after the empowering program. The cassava farmer's and tapioca producer's knowledge and lesson learn were collected from 35 farmers and 19 tapioca producers. After empowering program, farmers asked to cultivate Cassesart cassava variety (UJ-5). However, the UJ-5 productivity that was planted in $65.40 \mathrm{Ha}$ were declined. While, tapioca industries were also not directly increased farmers' welfare. Farmers' perspective in farming process was not changed after empowerment programs. Thirty-four farmers were not ready to build up new information. While, 16 from 19 tapioca producers (84.21\%) object to improve labor quality and welfare. The founded result was associated with conventional farming practices, low price product and education background in Pati District, and was increasingly weakened by limited knowledge transfer of modern farming.
\end{abstract}

@2020 by the authors. Licensee Indonesian Journal of Geography, Indonesia.

This article is an open access article distributed under the terms and conditions of the Creative Commons

Attribution(CC BY NC) licensehttps://creativecommons.org/licenses/by-nc/4.0/.

\section{Introduction}

Cassava is a high beneficial multipurpose agricultural product uses as a main material for carbohydrate source, paper production, fabric and plywood industries (Edhirej, Sapuan, Jawaid, \& Nur Ismarrubie Zahari, 2015). In Indonesia, tapioca (cassava flour) production reaches 5 million tons per year, while domestic need reaches 7 million tons per year. The shortage of tapioca consumption is fulfilled from imported cassava, for stabilizing supply, lowering prices, and producing better quality than local resources (Hutabarat, Setiyanto, Kustiari, \& Sulser, 2012; Magfiroh, Zainuddin, \& Setyawati, 2018). High amount of imported tapioca lowering local tapioca selling prices and falling down farmer's motivation and interest that threaten food chain sustainability (Demartini, Gaviglio, \& Pirani, 2017; Harris, Robinson, \& Griffiths, 2016). These problems massively impact cassava production and lowering farmer's income, especially in Pati District, Central Java. It is the main cassava producer in Central Java, and one of the largest national cassava suppliers in the last five years (BPS, 2020). It caused of vast agricultural land, and cassava agriculture is a main substitution crop for paddies production. Cassava agriculture plays important role to help community increase their income during drought season (Widodo, 2018). The cassava-tapioca agroindustry in Pati District is long period interaction that increases the economic value of cassava and provides jobs for local people. In fact, the long period interaction, community bond and social value among actors (farmer, employers and business owners) are social capital that needs to be improved because it is a part of sustainable food security (Abass et al., 2018). One of the effective ways to increase farmer productivity is by empowering them about agricultural modernization and improvement to catch the global demand.

Furthermore, low knowledges of farmers toward modern agriculture, facilities and technology such as grinding machines or dryers, has decreasing cassava productivity year by year (Croppenstedt, AndreGoldstein \& Rosas, 2013; Suryaningrat, Amilia, \& Choiron, 2015). Besides that, human resources (HR) aspects need to be developed to gain the cassava industry output (Hamidi \& Banowati, 2019). Hence, by empowering program, the farmers are freely accessed new information in cultivation, and actively involved in developing their business and social capital, which strengthen them to have better access to utilize the local resources (Hudayana, 2016)

The empowerment program (Luther, Mariyono, Purnagunawan, Satriatna, \& Siyaranamual, 2018; Putra et al., 2019) and modernization are important to increase cassava farming capacities and productivity (Luther et al., 2018). Regarding to previous research, empowering cassava farmers to use high quality seedbeds and agricultural modernization is effectively increase their income (Banowati, Indriyanti, Anisykurlillah, Pratikto, \& Sari, 2020), But, mostly, the empowerment program is conducted only for the farmers, and it is very rare for employer. The reason is because the business owners does not want to increase the production cost without direct profit. But the result of the empowering program for farmers should be monitored and evaluated 
periodically and developed as a lesson learned. Hence, this study was aimed to depict social knowledge and lesson learn from cassava-tapioca agroindustry actors in Pati District, before and after the empowerment program.

\section{The Methods}

This study was a case study report, which described using a phenomenological approach. The research locations were divided into two different areas, which were Morgoyoso and Tlogowungu Sub-districts, in Pati District (Figure 1).

The locations were chosen based on inclusion criteria: 1) both areas were main cassava producer area, 2) having the widest cassava farming areas in Pati District, and 3) there were tapioca production industries that directly integrated with cassava farming. The respondents were coming from 10 farmers from Margoyoso Ditrict and 25 farmers from Tlogowungu or 35 farmers in total, then as many as 19 tapioca producers consisted of 9 respondents from Margoyoso and 10 respondents from Tlogowungu District.

The social-science was assessed from respondent participation and actions in implementing five postempowerment aspects: information access (X1), participation (X2), business interest (X3), post-harvest processing (X4), and formation association (X5). Data was collected by structured observation method and following respondents' activities on farming and tapioca producing before and after empowerment to determine cognitive, affective, psychomotor, and conative levels in cassavatapioca agroindustry. Interviews and focus group discussions (FGD) was conducted using participatory rural appraisal (PRA) approaches regarding farmers' problems and solutions in facing unstable cassava prices. The FGD was conducted by involving relevant stakeholders: government representative, farmers, tapioca producers, entrepreneurs, and members of the Cassava Processing Association (PPSP).
During the empowering program, respondents were facilitated to access and understand about the modernization of cassava farming and sustainable production. Facilitation of empowerment promotes increased activity, knowledge integration and the introduction of mutual benefits. It also helps farmers to get information about mutual works in term of roles, authorities, responsibilities, reward systems and other attachments that result in collective action both in term of farming practices sector and tapioca production. The data obtained were then cross-tabulated and analyzed descriptively to find out social knowledge cassava-tapioca agroindustry.

\section{Result and Discussion}

The cassava productivity in Pati District contribute for more than $6 \%$ in national, and more than $43 \%$ in province (Table 1). The cassava business existence is main economic backbone of local community, and most important after paddies production.

In addition, Pati District is also the second largest cassava producer in Central Java with location quotient (LQ) reaching 0.96 (potentially support local economic and income). Total 269 units of tapioca industry located in Margoyoso Sub-district which employs 3,617 people. Interpretation of the coverage of SPOT 6 satellite images in November 2014 showed that $83.7 \%$ cassava land was mostly located in the northern part of Margoyoso Sub-district, specifically upper-slope under Muria Mount covering Tlogowungu, Margoyoso, Cluwak, Gembong, Margorejo, and Tayu Sub-district (Banowati, Ngabiyanto, Syukurilah, \& Danang Junior Trimasukmana, 2019). As well as $16.3 \%$ in the southern part, which is on the northern slope of Kendeng Mountains, covering Sukolilo, Kayen and Tambakromo Subdistrict.

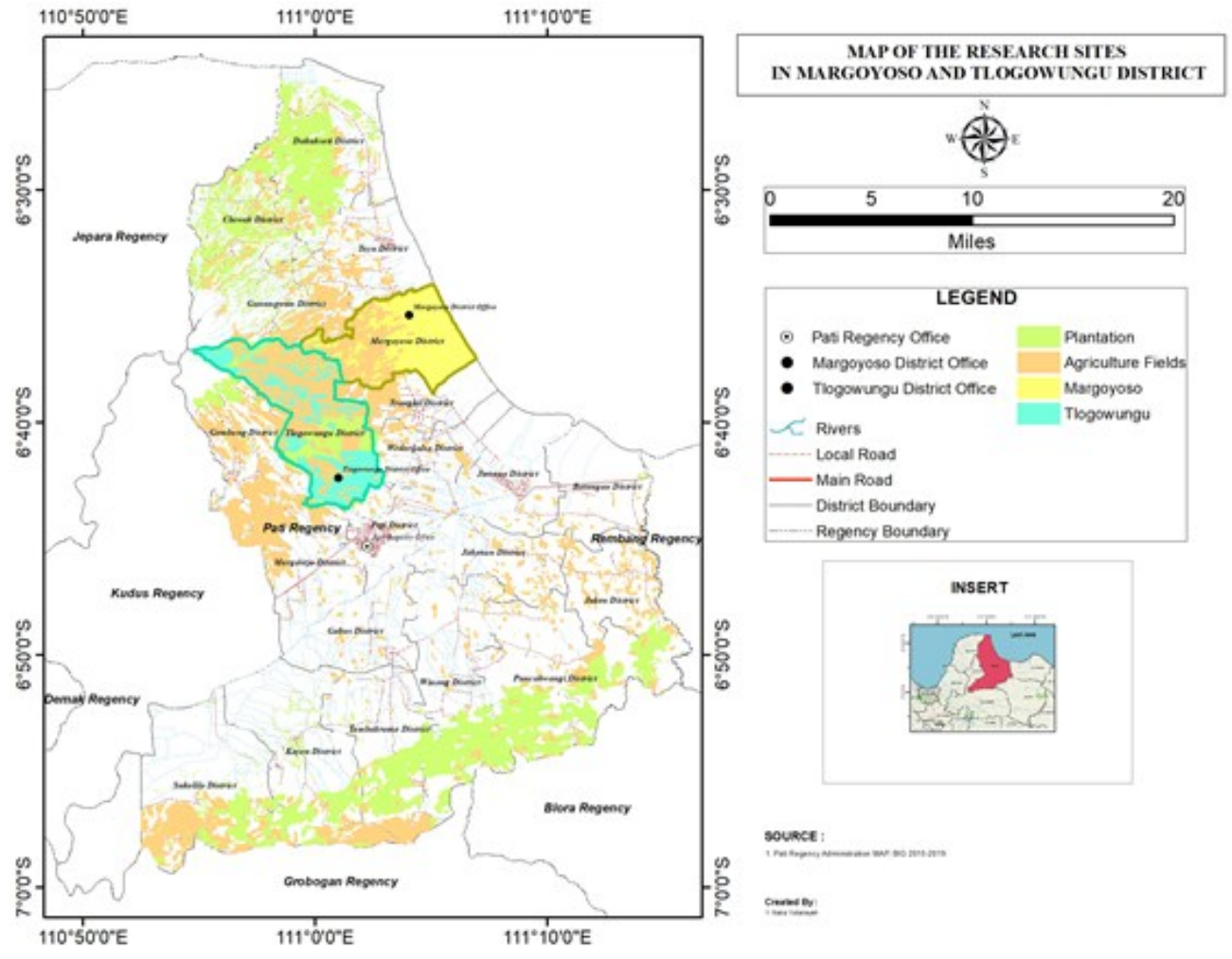

Figure 1. The map of the research sites (Margoyoso and Tlogowungu District) in Pati Region. 
Table 1. Pati District's cassava production for province and national contribution in 2015.

\begin{tabular}{lcc}
\hline & \multicolumn{2}{c}{ Contribution (\%) } \\
\hline Land Area & Province & National \\
Production & 10,07 & 1,60 \\
Productivity & 18,53 & 3,04 \\
\hline
\end{tabular}

Sources: Statistic Indonesia or Badan Pusat Statistik (BPS) accessed in 2019.

Table 2. Environmental factor in cassava production fields of Pati District

Indicator Standard environment parameter for cassava Existing condition in sample location planting

Climate and environment factors

Climate type

Temperature

Humidity

Sun light period

Planting media

Soil texture

Soil type

$\mathrm{pH}$

Drainage

Organic content

Dolomite

Existing demo plot

Altitude

10-700 masl

an, grumosol, and andosol.

4.5-8.0, ideally $\mathrm{pH} 5,8$

6.3

Well drainage

High content

Sudsy enough

crumbs, loose, and high organic compounds

latosol, reddish-yellow podsolic, mediteran

Elevation

Slope
C2, D2, and E1-E4*

$23{ }^{\circ} \mathrm{C}-39^{\circ} \mathrm{C}$

$67-72 \%$

12 hours/day

Source: Field survey (2017-2018). * Agro-climate criteria based on (Maru, Leo, \& Rahim, 2016)

Pati District has various land topography, ranging from coastal area to karst mountain because of physiographic influences. The soil condition is fertile and suitable for farming because contain of a high organic compound with normal $\mathrm{pH}$ and full irradiation 12 hours/ day. The type of constituent soil is quite varied; latosol, red-yellow and Mediterranean which support the growth of cassava (Table 2).

\section{Human Resources in the Agriculture Sector}

As many as 10 farmers with 36 family members in Margoyoso Sub-district worked on cassava farms covering 24.88 hectares or approximately 2.49 hectares/ farmer. The incomes from productive fields were used to support total of 46 people. Whereas in Tlogowungu sub-district, there were 25 cassava farmers, support total of 102 family members utilizes 40.52 ha or an average of $1.62 \mathrm{ha} /$ farmer as a livelihood. However, from the total productive fields, $40 \%$ of leased land (Table 3). Then, institutional status by the years of success in both sub-districts dominated by low-educated farmers.

The respondents were classified as middle-to-upperincome. However, the production of cassava farming that was carried out often loses because of unstable prices and even tends to be low over the past two years (Banowati \& Nugraha, 2018). 
Table 3. Farmers and tapioca producers profile in two sub-districts in Pati District.

\begin{tabular}{|c|c|c|c|c|c|c|c|c|c|c|}
\hline \multirow{3}{*}{ Profile } & \multicolumn{5}{|c|}{ Cassava Farmers } & \multicolumn{5}{|c|}{ Tapioca Producer } \\
\hline & \multicolumn{2}{|c|}{ Margoyoso } & \multicolumn{2}{|c|}{ Tlogowungu } & \multirow{2}{*}{ Total } & \multicolumn{2}{|c|}{ Margoyoso } & \multicolumn{2}{|c|}{ Tlogowungu } & \multirow{2}{*}{ Tota } \\
\hline & $\mathrm{f}$ & $\%$ & $\mathrm{f}$ & $\%$ & & $\mathrm{f}$ & $\%$ & $\mathrm{f}$ & $\%$ & \\
\hline \multicolumn{11}{|l|}{ Ages } \\
\hline $43-53$ & 7 & 25.93 & 20 & 74.07 & 27 & 5 & 35.71 & 9 & 64.29 & 14 \\
\hline $54-64$ & 3 & 37.50 & 5 & 62.50 & 8 & 4 & 80.00 & 1 & 20.00 & 5 \\
\hline \multicolumn{11}{|l|}{$\sum$ Family members } \\
\hline$\leq 3$ & 0 & 0.00 & 2 & 100.00 & 2 & - & - & - & - & - \\
\hline $4-5$ & 10 & 30.30 & 23 & 69.70 & 33 & - & - & - & - & - \\
\hline \multicolumn{11}{|l|}{$\sum$ Staff/ Employers } \\
\hline$\leq 10$ & - & - & - & - & - & 3 & 33.33 & 6 & 66.67 & 9 \\
\hline $11-20$ & - & - & - & - & - & 3 & 50.00 & 3 & 50.00 & 6 \\
\hline $21-30$ & - & - & - & - & - & 3 & 75.00 & 1 & 25.00 & 4 \\
\hline \multicolumn{11}{|l|}{ Educational } \\
\hline $6-9$ years (not finished) & 2 & 8.00 & 24 & 96.00 & 25 & 0 & 0.00 & 0 & 0.00 & 0 \\
\hline $\begin{array}{l}10-12 \text { years } \\
\text { (elementary) }\end{array}$ & 3 & 75.00 & 1 & 25.00 & 4 & 3 & 50.00 & 3 & 50.00 & 6 \\
\hline $\begin{array}{l}13-16 \text { years (junior } \\
\text { high) }\end{array}$ & 5 & 100.00 & 0 & 0.00 & 5 & 6 & 46.15 & 7 & 53.85 & 13 \\
\hline \multicolumn{11}{|l|}{ Land areas $(\mathrm{Ha})$} \\
\hline$<1$ & 1 & 12.50 & 7 & 87.50 & 8 & - & - & - & - & - \\
\hline $1-1.55$ & 2 & 33.33 & 4 & 66.67 & 6 & - & - & - & - & - \\
\hline $1.5-2$ & 1 & 12.50 & 7 & 87.50 & 8 & - & - & - & - & - \\
\hline $2-2,5$ & 0 & 0.00 & 2 & 100.00 & 2 & - & - & - & - & - \\
\hline $2,5-3$ & 3 & 37.50 & 5 & 62.50 & 8 & - & - & - & - & - \\
\hline$>3$ & 3 & 100.00 & 0 & 0.00 & 3 & - & - & - & - & - \\
\hline \multicolumn{11}{|l|}{ Land/ Business Statues } \\
\hline Owner & 10 & 40.00 & 15 & 60.00 & 25 & 9 & 47.37 & 10 & 52.63 & 19 \\
\hline Rent & 0 & 0.00 & 10 & 100.00 & 10 & 0 & 0.00 & 0 & 0.00 & 0 \\
\hline \multicolumn{11}{|l|}{ Productivity } \\
\hline$\leq 20$ & 3 & 21.43 & 11 & 78.57 & 14 & 1 & 50.00 & 1 & 50.00 & 2 \\
\hline $21-40$ & 1 & 33.33 & 2 & 66.67 & 3 & 3 & 37.50 & 5 & 62.50 & 8 \\
\hline $41-60$ & 3 & 30.00 & 7 & 70.00 & 10 & 1 & 50.00 & 1 & 50.00 & 2 \\
\hline $61-80$ & 3 & 37.50 & 5 & 62.50 & 8 & 2 & 66.67 & 1 & 33.33 & 3 \\
\hline$\geq 81$ & 0 & 0.00 & 0 & 0.00 & 0 & 2 & 50.00 & 2 & 50.00 & 4 \\
\hline
\end{tabular}

Sources: field observation and survey in 2017-2018

The cassava farming practices in both sub-districts were still conventional, using traditional information and tools by working on hoes, rained irrigation systems, no pesticides use and modern fertilizers. In addition, there was no special treatment to grow cassava plants, which was indicated by abundant weeds. It was probably due to a lack understanding in farming utilization that triggered by low formal education of the farmers. The low education directly contributes to accepting knowledge of agricultural modernization (Aboajah, Onjewu, Chia, \& Okeme, 2018). Cassava farmers in Pati District does not use modern technology to increase production. The carried-out farming processes are summarized in Table 4 . 


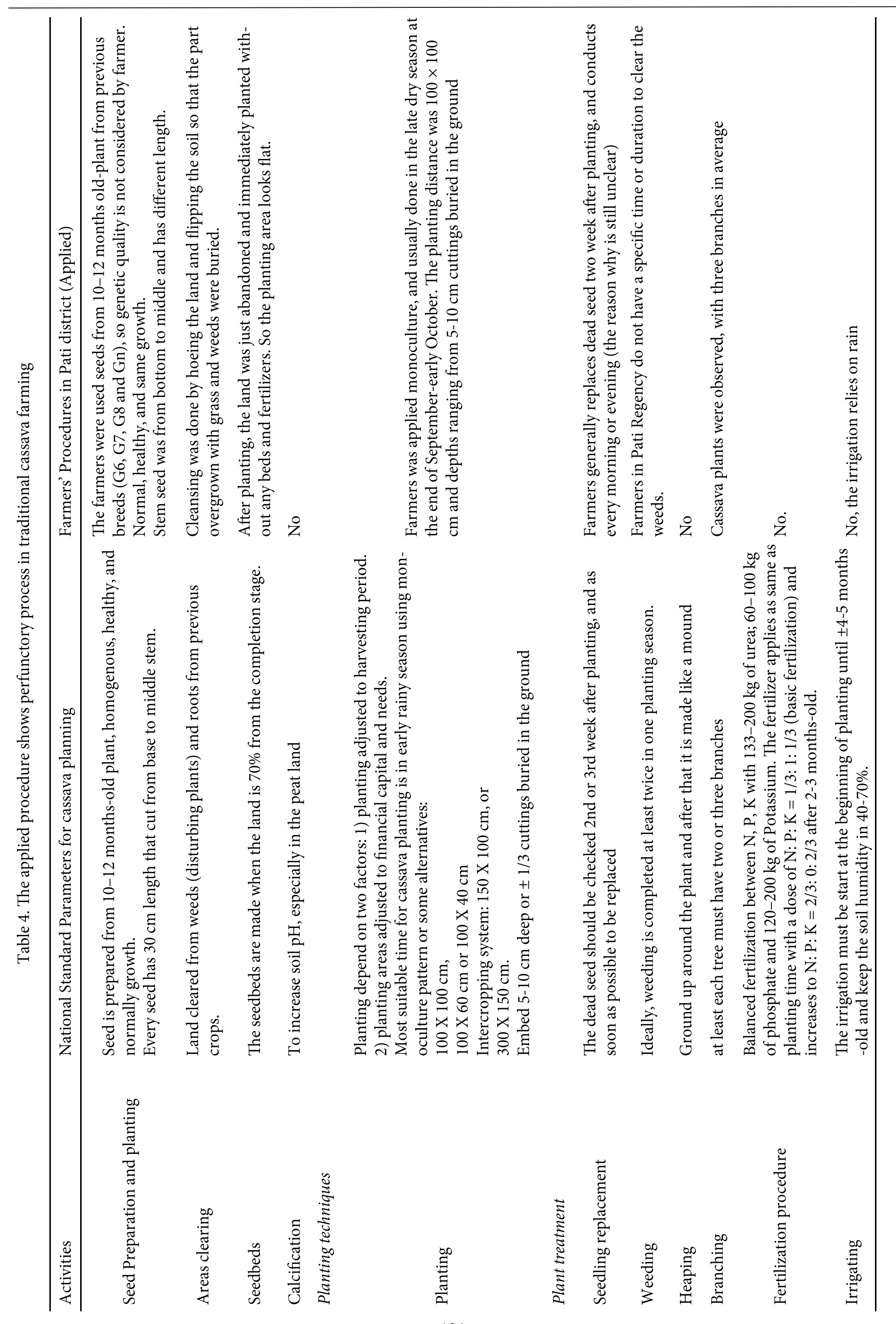



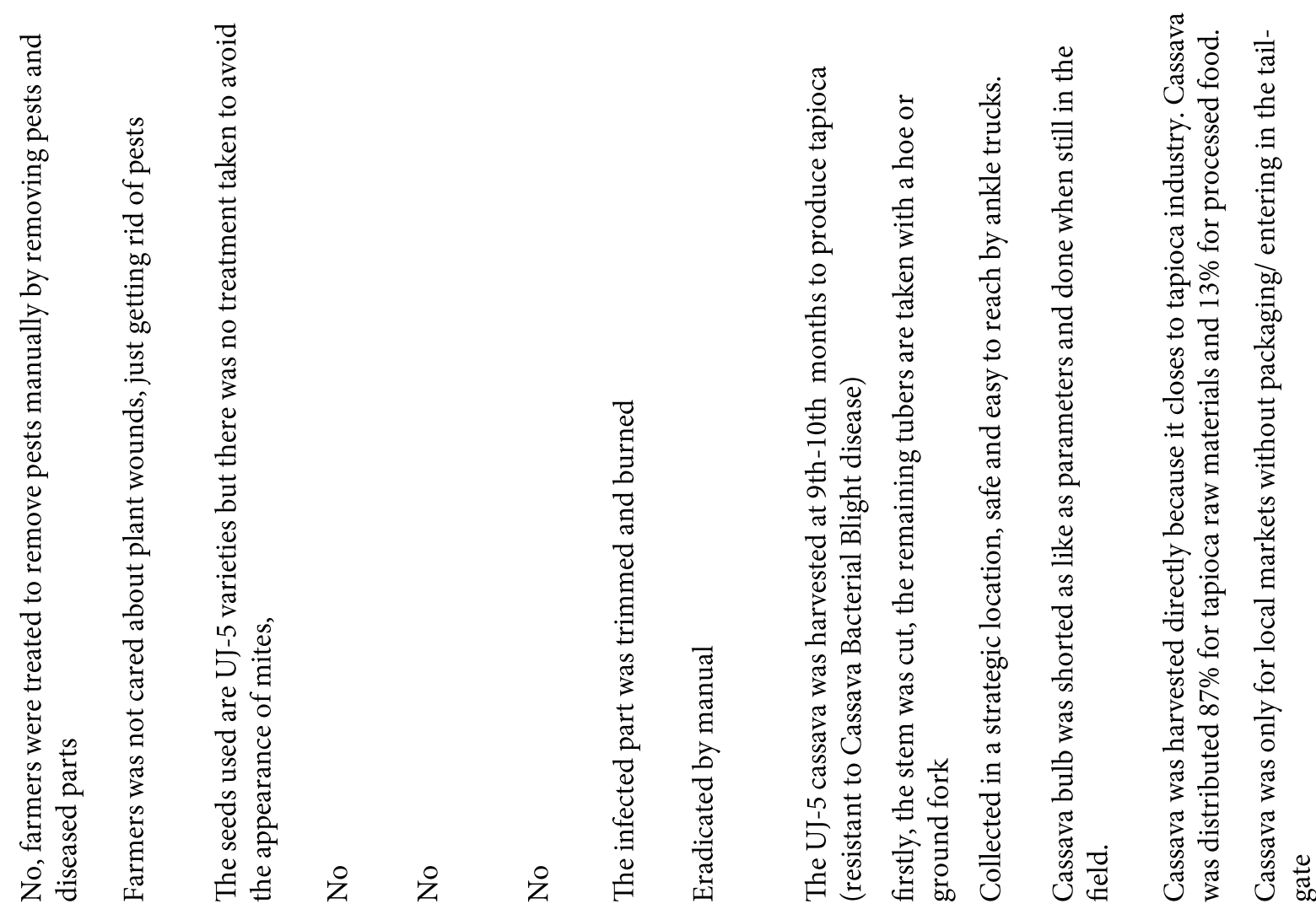

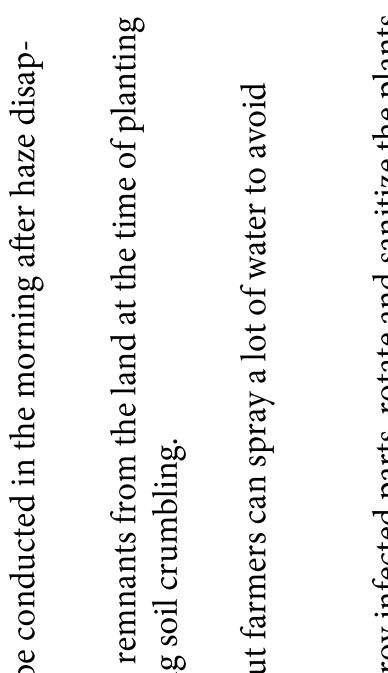

मे पै

¿

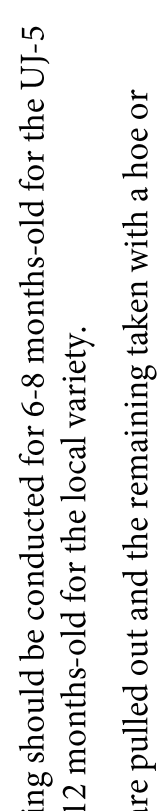

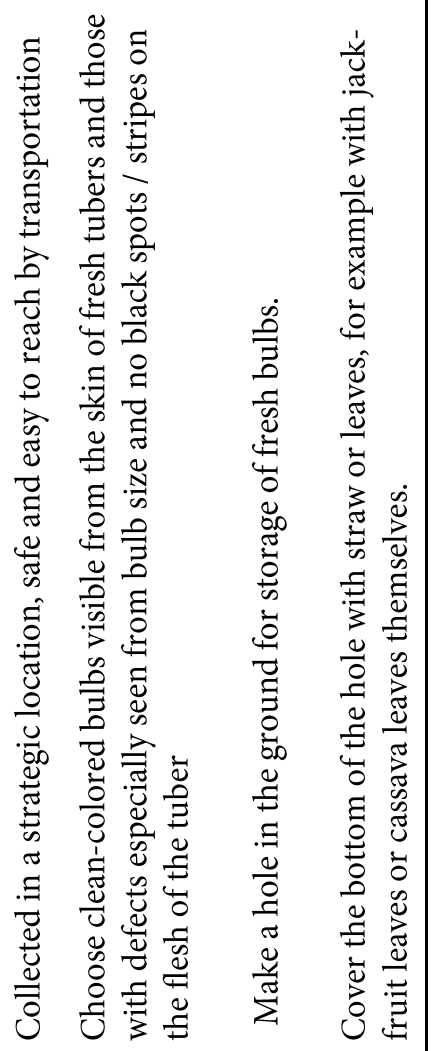

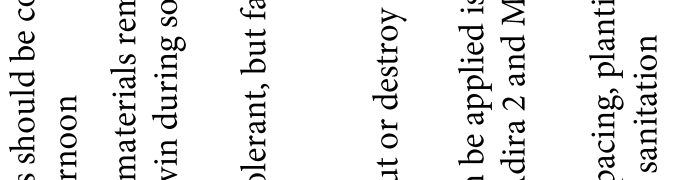

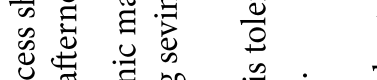

苛离

on $\cong$ :

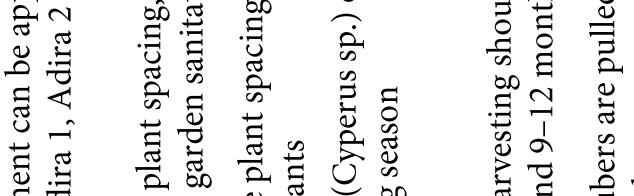

总言苛

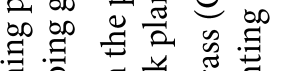

ส ส

焉

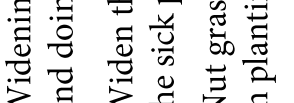

宽

总

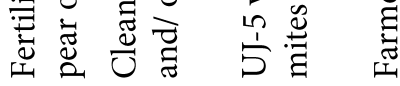

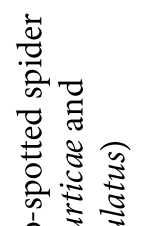

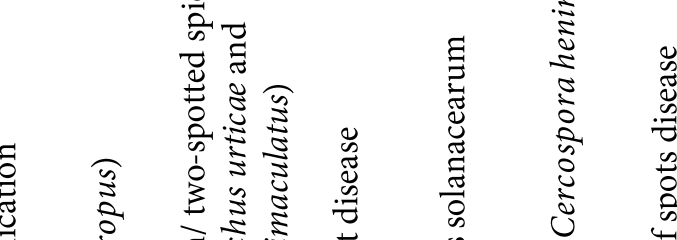

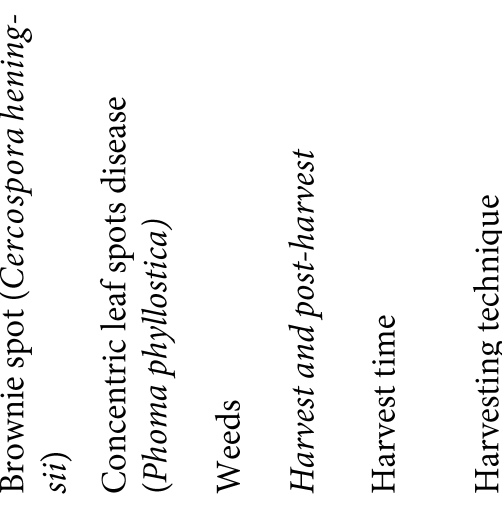

:

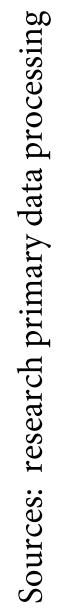


The main barriers in increasing cassava production and productivity were various factors that declined farmer's interest in cassava cultivation. Low production has triggered massively imported tapioca entering Pati District. In addition, local cassava price declines because it losing competitiveness with imported cassava which has better quality as a raw material for tapioca production. Furthermore, it made productive land areas shrinkage up to $30 \%$. Whereas the potential normative land in Pati District was far wider than productive land, while idle land was abandoned and disused.

In terms of biological plant sources, farmers using seventh generation (G7) and or more cassava seed as main plant breed. It was commonly found in the research site because it abundant, cheaper, and easier than certified seeds, and then low information of the cassava farmers to access high quality seed. The latter seed generation as plant breed decreases the genetic quality, especially in productionrelated-gene, which decrease quantity and quality of crop production from harvest to harvest (Kawuki, Nuwamanya, Herselman, \& Ferguson, 2011). It can assume that low incomes, low information access and difficult access to seedling development centers are also driving factors of low cassava productivity. This shows that cassava farmers are in a weak position and do not have a bargaining position to increase their production. Assessment of the empowerment parameters was shown that cognition level of the farmer was still at knowing and understanding levels (Table 5).

Most of the farmers tend to apply the knowledge that they get from an empowering program, especially in the cassava farming business aspect. It caused by cassava farming is a main job/ livelihood. Mostly, the farmers earn their money depend on cassava production only, which effectively can be earned every eight months, after that they just collecting lumbers and banana leaf to sell to the market. However, only seven farmers tried to access and analyze information related to cassava management, while other farmers were limited to knowing and understanding these activities. Low access to information of modern agriculture in Pati District, caused by education levels, age, low income. Technology access is very uncommon for farmers to use as communication tools such as smartphones and internet. Though, access agriculture information is very important in term of promoting and determining the adoption of modern agricultural production technology (Akudugu, Guo, \& Dadzie, 2012; Armstrong, Gandhi, \& Lanjekar, 2012; Chhachhar, Qureshi, Khushk, \& Maher, 2014; Hussain Awan, Ahmed, \& Hashim, 2019; Nwafor, Ogundeji, \& van der Westhuizen, 2020).

Meanwhile, managing human resource aspect was indicated that 16 people or $45.71 \%$ of cassava farmers were able to know the aspect, 9 people were passed applying process and 10 people were passed analyzing process of the effectiveness of paid labor. Because the process of farming depends on family business, there is no intention to establish a farmer group. Only around $5.71 \%$ of farmers have analyzed the sustainability of farmer groups while the rest were just recognized and not directly involved (Table 4). This information is in line with the fact that farmers in both sub-districts did not organize and there was no long-term planning in managing the business. The absence of structured planning is one of the things that inhibit sustainability and increased profits in the field of agroindustry (Ogunleye, Adeyemo, Bamire, \& Kehinde, 2017).

Table 5 Cognitive achievement of human resource after community empowerment

\begin{tabular}{lcccc}
\hline \multirow{2}{*}{ Parameters } & \multicolumn{4}{c}{ Farmers (people) } \\
\cline { 2 - 5 } Information access & Knowing & Understanding & Applying & Analyzing \\
Human resource participation & 12 & 12 & 7 & 4 \\
Business interest & - & 16 & 9 & 10 \\
Land processing & - & - & 35 & 9 \\
Association development & - & - & - & 2 \\
\hline
\end{tabular}

Source: field observation and survey in 2017-2018

Table 6. Affective, psychometric, and conative achievement of human resource after community empowerment (35 respondents).

\begin{tabular}{lccccccc}
\hline \multirow{2}{*}{ Parameter } & \multicolumn{3}{c}{ Affective } & \multicolumn{2}{c}{ Psychometric } & \multicolumn{2}{c}{ Conative } \\
\cline { 2 - 8 } & Agree & NA & Disagree & Skilled & Unskilled & Accept & Reject \\
\hline Information access & 8 & 27 & - & 1 & 34 & 11 & 24 \\
Human resource participa- & 16 & 19 & - & 35 & - & 10 & 25 \\
tion & 30 & 3 & 2 & 35 & - & 8 & 27 \\
Business interest & - & 35 & - & 35 & - & 35 & - \\
Land processing & 35 & - & - & 1 & 34 & 11 & 24 \\
Association establishment & & & & & & & \\
\hline
\end{tabular}

Source: field observation and survey. NA: Not answered 
In addition, the analysis of affective, psychomotor, and conative domains shows the low response parameters of empowerment. Weaknesses in accessing information and reluctance to follow up in group formation are indicated by post-empowerment farmers (Table 6).

The affective domains were observed in this study include feelings, interests, attitudes, and values. Identification of attitudes and abilities to receive and respond shows that only 8 farmers $(22.86 \%)$ actively access information, and rest of them was preferred to ignore information access. This is compatible with psychomotor values, where only one person cares and actively seeks information. Usually, information among farmers is generally spread by verbal messages. This information takes a long time to distribute, also decreases the quality. Even though, information plays an important role in the progress of innovation in agro-industry sector, especially related to modernization and facilities system development (Adekunle, Osazuwa, \& Raghavan, 2016). The low flow of information will prevent farmers from developing instruments and or expertise to increase their cassava production and productivity (Ajayi, Muhammed, Olah, \& Tsado, 2016; Ekanem \& T, 2018; Wyche \& Steinfield, 2016)

Whereas in human resource participation, it shows that most of the cassava farmers have low concern for labor management (Table 6). The low level of concern in managing the workforce is likely because farming activities only involve family members and rarely use laborers. The involvement of family members as laborers is considered cheaper and easier. The low awareness of managing labors also correlates with the formation of associations. Cassava farmers feel the need and care to develop the association if it benefits.

Behavioral changes in information access and association establishment aspect from conventional to modern farming was took long time, it was likely caused by conventional farming practices have been internalized into farmers. The formal education was accessed by the farmers was only up to elementary school and it became a limiting factor to the learning process (Aboajah et al., 2018; Mvodo \& Liang,
2012). This explains that farmers likely still rely on and practices hereditary knowledge in managing agricultural businesses. Because of their confident on common method declines their need for updating information. Cassava farming both through expansion and intensification model by using standardized seeds and more competitive technology were still lacked. According to Akudugu et al (2012) several factors such as economic, institutional and social have a significant influence on slowing pace of agricultural modernization.

Another difficulty faced by farmers was the market flow. The cassava farmers in Pati District follows traditional market flow from farmers to wholesaler or brokers to tapioca producers in the same area, while it only $13 \%$ that sold to outside region as food raw material.

Based on the business prospect, majority, farmers interests in developing cassava farming because of easy cultivation process and low crop failure risk, unless the plant is damaged by external factors (other than pests) (Nassar \& Ortiz, 2010). Because of the ability of cassava to grow easily, the farmers only carry out cultivation and do not do more effort to modernize farming management. However, in terms of the marketing process, farmers were constrained to find prospective markets, and depend on the presence of brokers (Figure 2). Whereas if the farmers were able to sell their cassava, they only sell it to small-scale tapioca producers at home industries.

Knowledge of tapioca production industry (Downstream of tapioca products)

Tapioca industries in Pati District localized in one area with cassava farming creates an agro-industrial area site and supporting economic resilience. Tapioca is used for food and non-food industries that also referred to downstream agroindustry products (Banowati et al., 2020) The tapioca producers profile in Pati District is generally small industries, with approximately 15 workers. Compared to a dozen tons per week of capacity production, which was only about $10 \%$ of the industrial workforce was effective, the rest was not effective to support production.

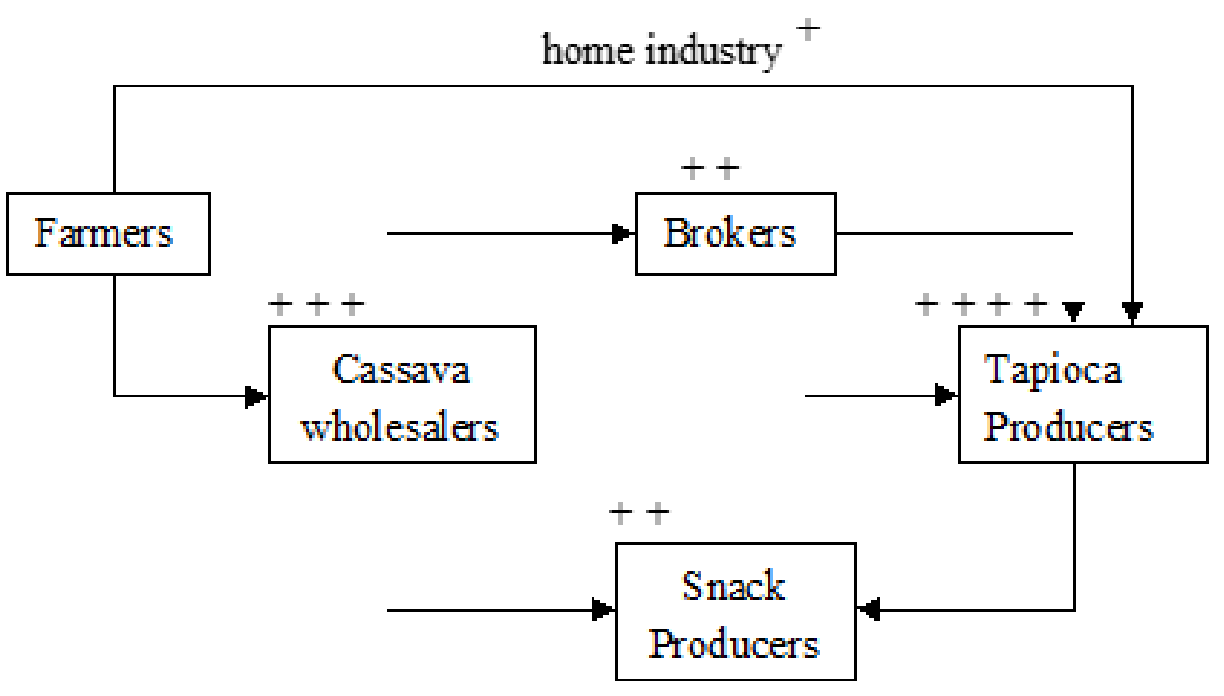

Figure 2. Current marketing flow of cassava and tapioca production. The plus mark (+) indicates the dominant distribution of cassava in the marketing flow (Source: field observation) 
Excessed industrial labor was possible came from local worker around tapioca producers, with has low skilled in the tapioca industry. However, industrial management defends this and keeps the labor to continue working because of mutualism conditions. By using local people, the tapioca producers can take advantages in working duration, because the labors were not constrained by travel time, high positive neighboring relationships, helping each other and positive environmental dynamics. However, mostly labor has low capacity and skills in tapioca producing, there was no effort from managerial to increase labor's capacity through training or empowerment program.

In return, the tapioca industry provides benefits to local incomes by reducing unemployment/ absorbing local workers, there were 3,617 people working in this sector. It very important because in Pati District, the population growth rate is $0.63 \%$ and there is no urbanization. Over past three years, the population has come in greater than migration and mortality.

Average tapioca industrial production capability was 6.8 tons per unit/ day, so at least $1,829.2$ tons/ day or 667.658 tons/ year of cassava needed by the producer to produce around 640.22 tons/ day of wet tapioca flour (Banowati et al., 2020). Bu t, to get high-quality tapioca both in quality and quantity, improvement in dry processing should be equipped, such as providing drying machines for tapioca producer. Recently, the drying process only relies on sunlight and is not stable, especially during the rainy season. Also, it takes a long time and reduces quality of the tapioca or called with "grosok" (brownie tapioca) lowering tapioca's prices. Generally, they sell grosok for IDR 9,000.00 - IDR 13,000 per $\mathrm{kg}$ or USD $0.62-0.90$ per $\mathrm{kg}$.
Basically, the tapioca industries in Pati District can be improved to get proper quality and quantity tapioca through agricultural and industrial revitalization. In addition, cassava agriculture and tapioca industries are competitive sectors with location quotient (LQ) value is 0.96 , so that the presence of local tapioca producer is expected to fill local needs rather than exported to other regions.

The empowering program was carried out showed that cognitively, tapioca producers actively created a process for accessing information, concern on human resource participation and still passionate in tapioca business (Table 7). It is likely because of the tapioca producers require to enlarge market to sell their products and manage their business sustainable. These demands make business owners actively seek information and conduct business management, including in terms of managing human resources/ labor they have (Wijayanti, Novianti, Karim, Sudaryanto, \& Carolina, 2017; Yulianto, Sukardi, Indrasti, \& Raharja, 2020)

Whereas in processing activities which include handling cassava from farmers and processing cassava into tapioca, majority of business actors were at the evaluation stage. This is probably caused by decreasing raw materials from farmers, so tapioca producers must recalculate the available raw materials stock and look for alternative raw materials for running the tapioca production. In the aspect of association establishment, producers tend to be more caring than cassava farmers, indicated by most respondents has joined in a producer group. This aspect is considered as an important step to keep their business on the right track, because business association plays an important role in product commercialization activities and sharing information about product update (Forsythe, Posthumus, \& Martin, 2016).

Table 7. Cognitive achievement of human resource after community empowerment in tapioca production sector

\begin{tabular}{lcccc}
\hline \multicolumn{1}{c}{ Parameters } & \multicolumn{4}{c}{ Producers (people) } \\
\cline { 2 - 4 } Information access & Applying & Analyzing & Evaluating & Creating \\
Human resource participation & - & - & - & 19 \\
Business interest & - & - & - & 19 \\
Processing & - & - & 4 & 15 \\
Association establishment & - & - & 13 & 6 \\
\hline
\end{tabular}

Table 8. Affective, psychometric, and conative achievement of human resource after community empowerment.

\begin{tabular}{lcccccc}
\hline \multirow{2}{*}{ Parameters } & \multicolumn{2}{c}{ Affective } & \multicolumn{2}{c}{ Psychometric } & \multicolumn{2}{c}{ Conative } \\
\cline { 2 - 7 } & Agree & NA & Skilled & Unskilled & Accept & Reject \\
\hline Information access & 19 & - & 17 & 2 & 17 & 2 \\
Human resource participation & 3 & 16 & 3 & 16 & 3 & 16 \\
Business interest & 19 & - & 19 & - & 19 & - \\
Processing & 19 & - & 19 & - & 19 & - \\
Association development & 19 & - & 19 & - & 19 & - \\
\hline
\end{tabular}

Source: field observation and survey. NA: Not answered 
Mostly, tapioca producers took concern in carrying out all empowerment activities except for the human resources participation aspect (Table 8 ). This is probably due to the production model that relies on local people as cheap-local labor. Abundant, inexpensive, and unskilled local workers are probably the reason for positive response in the low human resources participation aspect. Local workers tend to accept company decisions because they do not have a bargaining position, besides being the main business holder, the company has full authority over workers. In this part, tapioca producers tend to agree and follow up on all aspects or activities learned in empowerment except human resource management. The tapioca producers more prefer to reach daily target rather than provide labor training as an infestation. Planning for sustainable tapioca productivity is not too visible during observation. It is probably due to common practiced management of farming without modernizing the facilities and low knowledge on increasing tapioca quality and quantity. In addition, the low price of tapioca and the lack of market places is one of the main triggers that slowing productivity.

\section{Conclusion}

The productivity of Cassesart varieties (UJ-5), which were planted on the land of $65.40 \mathrm{Ha}$ in two sub-districts, was decreased because of low selling prices. Human resources empowerment in upstream and downstream leads to understanding farmers and producers' condition and behavior trend in four aspects: cognitive, conative, affective, and psychomotor. It related to the achievement of independence in the agro-industrial area. Identification of willingness in farmers in term of applying empowerment result was showed that the farmers in majority were still inclined to use agricultural models that have been used for generations. The main problems in implementing empowerment knowledge were caused by low income, education, and individual worker, based on habits in farming. Aspects of human resource participation, especially in the workers and modernization technology management need special attention to both agriculture and the tapioca industry. In the tapioca industry in Pati District, it is specifically necessary to revitalize machinery and production methods, especially in drying processing to increase productivity. Furthermore, the monitoring and evaluation of empowering program should be established frequently to collect better understanding of farmers and develop more appropriate approaches.

\section{Acknowledgement}

Researchers would like to thank to the Directorate of Research and Community Service Directorate General of Research and Technology Strengthening and Development of the Ministry of Research, Technology, and Higher Education for funding this research contracts for fiscal year 2018, Number: 117.2.4/UN37/PPK.3.1/ 2018.

\section{Author Contribution}

This article was presented as a collaborative works from the authors. E. Banowati, as the main author contributes in core ideas development, social and geographical data collection and analysis, and article finalization and publication, then the second author D. R. Indrayati responsible in pest identification, biological and environmental data collection, also contributes in data analysis and presentation for publication. I. Anisyukurilah and H. H. Pratikto together contributes in social and economic analysis, demography data and cassava field mapping, also contributes in result and discussion arrangement and review.

\section{Reference}

Abass, A. B., Awoyale, W., Alenkhe, B., Malu, N., Asiru, B. W., Manyong, V., \& Sanginga, N. (2018). Can food technology innovation change the status of a food security crop? A review of cassava transformation into "bread" in Africa. Food Reviews International, 34(1), 87-102. https:// doi.org/10.1080/87559129.2016.1239207

Aboajah, F. N., Onjewu, S. S., Chia, J. I., \& Okeme, S. (2018). Socioeconomic Determinants of Cassava Production in Benue State, Nigeria. International Journal of Environment, Agriculture and Biotechnology, 3(2), 550-557. https:// doi.org/10.22161/ijeab/3.2.32

Adekunle, A., Osazuwa, P., \& Raghavan, V. (2016). Socio-economic determinants of agricultural mechanisation in Africa: A research note based on cassava cultivation mechanisation. Technological Forecasting and Social Change, 112, 313-319. https://doi.org/10.1016/j.techfore.2016.09.003

Ajayi, O. J., Muhammed, Y., Olah, F., \& Tsado, J. H. (2016). Effects of Information and Communication Technology (ICT) Usage on Cassava Production in Oturkpo Local Government Area, Benue State, Nigeria. Production Agriculture and Technology, 12(2), 49-58.

Akudugu, M. A., Guo, E., \& Dadzie, S. K. (2012). Adoption of Modern Agricultural Production Technologies by Farm Households in Ghana: What Factors Influence their Decisions? Journal of Biology, Agriculture and Healthcare, 2 (3), 1-13. Retrieved from https://www.researchgate.net/ profile/Samuel_Dadzie/ publication/235751741_Adoption_of_mo

dern_agricultural_production_technologies_by_farm_hous eholds_in_Ghana_What_factors_influence_their_decisions/ links/00463533b1249ebdf1000000.pdf

Armstrong, L. J., Gandhi, N., \& Lanjekar, K. (2012). Use of Information and Communication Technology (ICT) tools by rural farmers in Ratnagiri District of Maharastra, India. Proceedings - International Conference on Communication Systems and Network Technologies, CSNT 2012, 2012, 950955. https://doi.org/10.1109/CSNT.2012.202

Banowati, E., Indriyanti, D. R., Anisykurlillah, I., Pratikto, H. H., \& Sari, Y. (2020). Increasing the competency of cassava farmers as a revitalization efforts of tapioca industries for food private realization. International Journal of GEOMATE, 19(72), 117-122. https:// doi.org/10.21660/2020.72.ICGEO17

Banowati, E., Ngabiyanto, N., Syukurilah, I. A., \& Danang Junior Trimasukmana. (2019). The Empowerment of Upstream Downstream Human Resources to Revitalise Tapioca Industry. MImbar, 34(2), 452-461.

Banowati, E., \& Nugraha, S. B. (2018). Land Utilization Pattern in the Indonesian Forest: Cassava Cultivation in an Agroforestal System. In Plant Competition in Cropping Systems (p. 13). https://doi.org/10.1016/ j.colsurfa.2011.12.014

BPS. (2020). Luas Panen Ubi Kayu Menurut Provinsi (ha), 19932015. Retrieved July 15, 2020, from https://www.bps.go.id/ dynamictable/2015/09/09/879/luas-panen-ubi-kayumenurut-provinsi-ha-1993-2015.html

Chhachhar, A. R., Qureshi, B., Khushk, G. M., \& Maher, Z. A. (2014). Use of Mobile Phone among Farmers for Agriculture Information. European Journal of Scientific 
Research, 119(2), 265-271. Retrieved from http:// www.europeanjournalofscientificresearch.com

Croppenstedt, AndreGoldstein, M., \& Rosas, N. (2013). Inefficiencies, Segregation, and Low Productivity Traps. Gender and Agriculture Inefficiencies, Segregation, and Low Productivity Traps, (February).

Demartini, E., Gaviglio, A., \& Pirani, A. (2017). Farmers' motivation and perceived effects of participating in short food supply chains: Evidence from a North Italian survey. Agricultural Economics (Czech Republic), 63(5), 204-216. https://doi.org/10.17221/323/2015-AGRICECON

Edhirej, A., Sapuan, S. M., Jawaid, M., \& Nur Ismarrubie Zahari. (2015). Cassava: Its Polymer, Fiber, Composite, and Application. Polymers and Polymer Composites, 38(3), 555 -570. https://doi.org/10.1002/pc

Ekanem, J., \& T, A. (2018). Diagnosing the Dimensions of Benefits and Constraints of Information and Communication Technology (ICT) Utilization among Cassava Farmers in Uyo Agricultural Zone, South-South Nigeria. Asian Journal of Agricultural Extension, Economics \& Sociology, 25(2), 110. https://doi.org/10.9734/ajaees/2018/41752

Forsythe, L., Posthumus, H., \& Martin, A. (2016). A crop of one's own? Women's experiences of cassava commercialization in Nigeria and Malawi. Journal of Gender, Agriculture and Food Security, 1(2), 110-120.

Hamidi, M. A., \& Banowati, E. (2019). Utilization of mocaf flour (modified cassava flour) for revitalization of the use tapioca flour in communities for empowering hulu-hilir human resources in wonogiri regency. IOP Conference Series: Earth and Environmental Science, 243(1). https:// doi.org/10.1088/1755-1315/243/1/012081

Harris, F., Robinson, G. M., \& Griffiths, I. (2016). A study of the motivations and influences on farmers' decisions to leave the organic farming sector in the United Kingdom. In Sustainable Rural Systems: Sustainable Agriculture and Rural Communities (pp. 99-112).

Hudayana, B. (2016). Empowering Rural Women in Java through Cassava Culinary Business in The Refrom Era. 7th International Conference and Field Study in Malaysia, (December), 137-145. Kuala Lumpur: UTM.

Hussain Awan, S., Ahmed, S., \& Hashim, M. Z. (2019). Use of Information and Communication Technology ICT in Agriculture to Uplift Small Scale Farmers in Rural Pakistan. American Journal of Engineering and Technology Management, 4(1), 25. https://doi.org/10.11648/ j.ajetm.20190401.14

Hutabarat, B., Setiyanto, A., Kustiari, R., \& Sulser, T. B. (2012). Conjecturing Production, Imports and Consumption of Horticulture In Indonesia In 2050: A Gams Simulation Through Changes In Yields Induced by Climate Change. Jurnal Agro Ekonomi, 30(1), 1-23.

Kawuki, R. S., Nuwamanya, E., Herselman, L., \& Ferguson, M. E. (2011). Segregation of selected agronomic traits in six S 1 cassava families. Journal of Plant Breeding and Crop Science, 3(8), 154-160.

Luther, G. C., Mariyono, J., Purnagunawan, R. M., Satriatna, B., \& Siyaranamual, M. (2018). Impacts of farmer field schools on productivity of vegetable farming in Indonesia. Natural Resources Forum, 42(2), 71-82. https://doi.org/10.1111/1477 $-8947.12144$
Magfiroh, I. S., Zainuddin, A., \& Setyawati, I. K. (2018). Maize Supply Response in Indonesia. Buletin Ilmiah Litbang Perdagangan, 12(1), 47-72. https://doi.org/10.30908/ bilp.v12i1.309

Maru, R., Leo, M. N. Z., \& Rahim, S. (2016). Oldeman Climate Zoning for the Agricultural Area. International Conferenve on Mathematics, Science, Technology, Education and Their Application, (October), 511-521. Makasar.

Mvodo, E. S. M., \& Liang, D. (2012). Cassava sector development in Cameroon: Production and marketing factors affecting price. Agricultural Sciences, 03(05), 651-657. https:// doi.org/10.4236/as.2012.35078

Nassar, N., \& Ortiz, R. (2010). Breeding cassava to feed the poor. Scientific American, 302(5), 78-85.

Nwafor, C. U., Ogundeji, A. A., \& van der Westhuizen, C. (2020). Adoption of ICT-based information sources and market participation among smallholder livestock farmers in South Africa. Agriculture (Switzerland), 10(2). https:// doi.org/10.3390/agriculture10020044

Ogunleye, A. S., Adeyemo, R., Bamire, A. S., \& Kehinde, A. D. (2017). Assessment of profitability and efficiency of cassava production among government and non-government assisted farmers association in Osun State, Nigeria. African Journal of Rural Development, 2(June), 225-233.

Putra, H. E., Tengah, K., Gorontalo, K., Marzaman, A., Gorontalo, U., \& Gorontalo, K. (2019). Application of Participatory Leadership in Optimizing the Potential of the Agricultural Sector. Gorontalo: Journal of Government and Political Sudies, 2(2), 50-58.

Suryaningrat, I. B., Amilia, W., \& Choiron, M. (2015). Current Condition of Agroindustrial Supply Chain of Cassava Products: A Case Survey of East Java, Indonesia. Agriculture and Agricultural Science Procedia, 3, 137-142. https:// doi.org/10.1016/j.aaspro.2015.01.027

Widodo, Y. (2018). Cassava Productivity for Eradicating Hunger and Poverty in Rural Areas of Indonesia. Rural Sustainability Research, 39(334), 32-40. https:// doi.org/10.2478/plua-2018-0005

Wijayanti, F., Novianti, F., Karim, M. A., Sudaryanto, A., \& Carolina, C. (2017). How to Improve Business Performance: A Financial Analysis on Micro Tapioca Industry. 2nt International Conference on Economic Education Anf Entrepreneurship, (October 2018), 240-246. https:// doi.org/10.5220/0006884002400246

Wyche, S., \& Steinfield, C. (2016). Why Don't Farmers Use Cell Phones to Access Market Prices? Technology Affordances and Barriers to Market Information Services Adoption in Rural Kenya. Information Technology for Development, 22 (2), 320-333. https:// doi.org/10.1080/02681102.2015.1048184

Yulianto, K., Sukardi, Indrasti, N. S., \& Raharja, S. (2020). Situational analysis and prospect of interest-free financing in tapioca agro-industry. IOP Conference Series: Earth and Environmental Science, 472, 012051. https:// doi.org/10.1088/1755-1315/472/1/012051 